\title{
AS MUITAS FACES DE NOSSA SENHORA DOS REMÉDIOS
}

\section{Lidice Meyer Pinto Ribeiro ${ }^{1}$}

Resumo: Através da análise da iconografia de Nossa Senhora dos Remédios, o objetivo deste trabalho é identificar a difusão desta devoção e suas características marcantes e diferenciadoras no que tange a sua íntima correlação com o ideal de libertação de cativos. Para tanto realizou-se pesquisas de campo na França, Espanha, Portugal, Itália (Roma, Arquivos Secretos do Vaticano) e em diversos locais do Brasil, sempre em busca de imagens representativas de Nossa Senhora dos Remédios. Observou-se que a mudança ocorrida na devoção do século XII ao século XXI pode ser percebida através das alteraçóes sofridas pelas representaçóes físicas desta invocação.

Palavras-chave: Nossa Senhora dos Remédios. Ordem da Santíssima Trindade e Redenção de Cativos. Trinitários. Nossa Senhora do Leite.

Abstract: This paper analyse the spread of Our Lady of Good Remedy's devotion and its distinguishing characteristics in relation to its intimate correlation with the ideal of captive liberation. through its iconography In orther to obtain this, the research was carried out in France, Spain, Portugal, Italy (Rome, Vatican Secret Archives) and in various places in Brazil, always searching for representative images of Our Lady of Good Remedy. It was observed that the change in devotion from the twelfth to the twenty-first century can be perceived through the changes undergone by the physical representations of this invocation.

Keywords: Our Lady of Good Remedy. Order of Saint Trinity and Redemption of Captives. Trinitarians. Our Lady of the Milk.

1 Pós-doutoranda em Estudos de Globalização pela Universidade Aberta de Lisboal CLEPUL. Pós-Doutora em Antropologia e História pela Universidade de São Paulo. Doutora em Antropologia Social pela mesma Universidade. Docente do Programa de Pós-Graduação em Ciências da Religiáo da Universidade Presbiteriana Mackenzie. Contato: lidice.ribeiro@mackenzie.br

Debates do NER, Porto Alegre, ANo i 8, N. 32, P. 259-287, JUl./DeZ. 20 I 7 